\title{
S100A12 as a Marker to Predict Cardiovascular Events in Patients With Chronic Coronary Artery Disease
}

\author{
Toshinobu Saito, MD; Yukihiro Hojo, MD, PhD; Yukako Ogoyama, MD; \\ Masahiro Hirose, MD; Tomokazu Ikemoto, MD; Takaaki Katsuki, MD, PhD; \\ Kazuyuki Shimada, MD, PhD; Kazuomi Kario, MD, PhD
}

\begin{abstract}
Background: S100A12, a calgranulin family protein released from white blood cells, is involved in inflammatory cardiovascular disease. It was hypothesized that the plasma level of S100A12 can be used to predict outcome in patients with chronic coronary artery disease (CAD). The purpose of this study was to clarify the clinical significance of S100A12 in patients with stable CAD.
\end{abstract}

\begin{abstract}
Methods and Results: A total of 652 patients with stable CAD were studied. All patients underwent percutaneous coronary intervention and successful revascularization. Major adverse cardiovascular events (MACE) were defined as a composite of events of CHF, recurrence of angina pectoris, acute myocardial infarction, stroke, critical arrhythmia, intervention to peripheral arteries and cardiac death. The mean follow-up period was $973 \pm 639$ days. MACE occurred in 108 patients (16.6\%). Plasma S100A12 level had a significant positive correlation with high-sensitivity C-reactive protein (hs-CRP) level. On Kaplan-Meier curve analysis the incidence of MACE was significantly different among S100A12 quartiles ( $P=0.026)$. The highest $S 100 A 12$ quartile (Q4) had a significantly higher MACE rate than the lowest quartile (Q1) $(P=0.002)$. In contrast, hs-CRP was not significant for predicting MACE in the present subjects $(P=0.074)$. A Cox proportional hazard model showed that $S 100 A 12$ was an independent factor for predicting MACE in multivariate models.
\end{abstract}

Conclusions: S100A12 could be a novel biomarker for predicting cardiovascular events for predicting MACE in patients with stable CAD. (Circ J 2012; 76: 2647-2652)

Key Words: Atherosclerosis; Inflammation; Leukocyte

D espite the recent development of a coronary revascularization method for patients with chronic coronary artery disease (CAD), critical cardiovascular events such as acute myocardial infarction and congestive heart failure (CHF) remain problematic. A drug-eluting stent has drastically reduced target lesion restenosis as indicated in the SIRIUS trial, ${ }^{1-4}$ but the prognosis of CAD patients did not improve sufficiently and the number of major adverse cardiovascular events (MACE) did not decrease even after the stent implantation. ${ }^{4,5}$ Therefore, the detection and management of high-risk patients is important.

$\mathrm{S} 100 \mathrm{~A} 12$ is a member of the $\mathrm{S} 100$ calcium-binding protein family secreted from white blood cells. To date, more than 20 members of this family have been identified. Each isoform of S100 has tissue-specific expression. ${ }^{6}$ S100A12 is expressed in granulocytes and activated monocytes/macrophages and is characterized by 2 calcium-binding EF-hands and consists of 9-14-kDa low-molecular acidic proteins. ${ }^{7-9}$ Interestingly, S100A12 binds to receptor for advanced glycation-end prod- ucts (RAGE), leading to the upregulation of nuclear factor $\kappa \mathrm{B}$ $(\mathrm{NF} \kappa \mathrm{B})$ expression. ${ }^{6}$ Binding of S100A12 to RAGE induces secretion of cytokines via an NFKB-mediated mechanism. Thus S100A12 is also termed extracellular newly identified RAGE-binding protein (EN-RAGE). In addition, S100A12 has remarkable chemotactic activity, comparable with other chemotactic agents. ${ }^{10} \mathrm{~S} 100 \mathrm{~A} 12$ is a mediator that increases inflammation and tumorigenesis, ${ }^{11-13}$ together with other cytokines. ${ }^{10,14}$

S100A12 is reported to be involved in chronic inflammatory diseases such as rheumatoid arthritis, ${ }^{15,16}$ inflammatory bowel syndrome ${ }^{11}$ and Kawasaki disease. ${ }^{17}$ We hypothesized that S100A12, a newly identified atherogenic molecule, is related to cardiovascular events in atherosclerotic coronary disease. In this study we measured plasma levels of S100A12 and investigated their clinical significance in patients with chronic CAD.

Received January 23, 2012; revised manuscript received May 21, 2012; accepted June 13, 2012; released online July 7, 2012 Time for primary review: 20 days

Department of Cardiology, Jichi Medical University, Shimotsuke, Japan

Mailing address: Yukihiro Hojo, MD, PhD, Department of Cardiology, Jichi Medical University, 3311 Yakushiji, Shimotsuke 329-0498, Japan. E-mail: yhojo@jichi.ac.jp

ISSN-1346-9843 doi:10.1253/circj.CJ-12-0093

All rights are reserved to the Japanese Circulation Society. For permissions, please e-mail: cj@j-circ.or.jp 


\begin{tabular}{lc|}
\hline Table 1. Baseline Subject Characteristics & \\
Age (years), mean \pm SD & $64.1 \pm 9.6$ \\
Male & $533(81.7)$ \\
BMI $\left(\mathrm{kg} / \mathrm{m}^{2}\right)$ & $24.2 \pm 0.1$ \\
Hypertension & $481(73.8)$ \\
Dyslipidemia & $427(65.5)$ \\
DM & $278(42.6)$ \\
Current smoker & $234(35.9)$ \\
FH of CAD & $139(21.3)$ \\
hs-CRP (ng/ml) & $2,877 \pm 277$ \\
eGFR (ml-min $\left.{ }^{-1} \cdot 1.73 \mathrm{~m}^{-2}\right)$ & $68.1 \pm 0.87$ \\
LVEF $(\%)$ & $60.7 \pm 0.5$ \\
History of Ml & $206(31.6)$ \\
No. stenotic major vessels & \\
0-vessel disease & $1(0.2)$ \\
1-vessel disease & $260(39.9)$ \\
2-vessel disease & $243(37.3)$ \\
3-vessel disease & $109(16.7)$ \\
Left main trunk & $39(6.0)$ \\
\hline
\end{tabular}

Data given as mean \pm SEM or $n(\%)$.

$\mathrm{BMI}$, body mass index; CAD, coronary artery disease; $\mathrm{DM}$, diabetes mellitus; eGFR, estimated glomerular filtration rate; $\mathrm{FH}$, family history; hs-CRP, high-sensitivity C-reactive protein; LVEF, left ventricular ejection fraction; MI, myocardial infarction.

\section{Methods}

\section{Patients}

Consecutive patients who underwent coronary angiography at Jichi Medical University Hospital between November 2002 and August 2010 were included in this study. We studied 652 patients with stable CAD who underwent successful percutaneous coronary intervention (PCI) at the hospital. PCI was performed by standard catheterization via a 5- or 6-Fr sheath inserted into the patient's femoral or radial arteries with local anesthesia. Aspirin and heparin were given before the PCI. Coronary stents were implanted into the stenotic lesions using a balloon-mounted stent delivery system. Directional atherectomy and rotational atherectomy were performed according to the operators' decision. After the PCI, all patients were followed up regularly every 4-8 weeks. MACE was defined as a composite of events of readmission for $\mathrm{CHF}$, readmission due to the recurrence of angina pectoris, acute myocardial infarction, stroke, critical arrhythmia, intervention to peripheral arteries and cardiac death.

We excluded patients with acute coronary syndrome, acute inflammatory disease, acute renal failure, hematological disorder, collagen disease, malignancy and those taking immunosuppressive medicine. If successful coronary revascularization was not accomplished, we also excluded the patients. Hypertension, dyslipidemia and diabetes mellitus were diagnosed according to the criteria in the guidelines for each disease. ${ }^{18-20}$ Left ventricular ejection fraction (LVEF) was measured using echocardiography with modified Simpson's method.

The Ethics Committee of Jichi Medical University approved the study protocol. All patients enrolled in this study provided informed consent.

\section{Measurement of Plasma Biomarkers}

Peripheral blood was taken before cardiac catheterization. Anti-coagulated samples were then centrifuged immediately at $1,000 \times \mathrm{g}\left(4^{\circ} \mathrm{C}, 15 \mathrm{~min}\right)$ and stored at $-80^{\circ} \mathrm{C}$ until the assay.
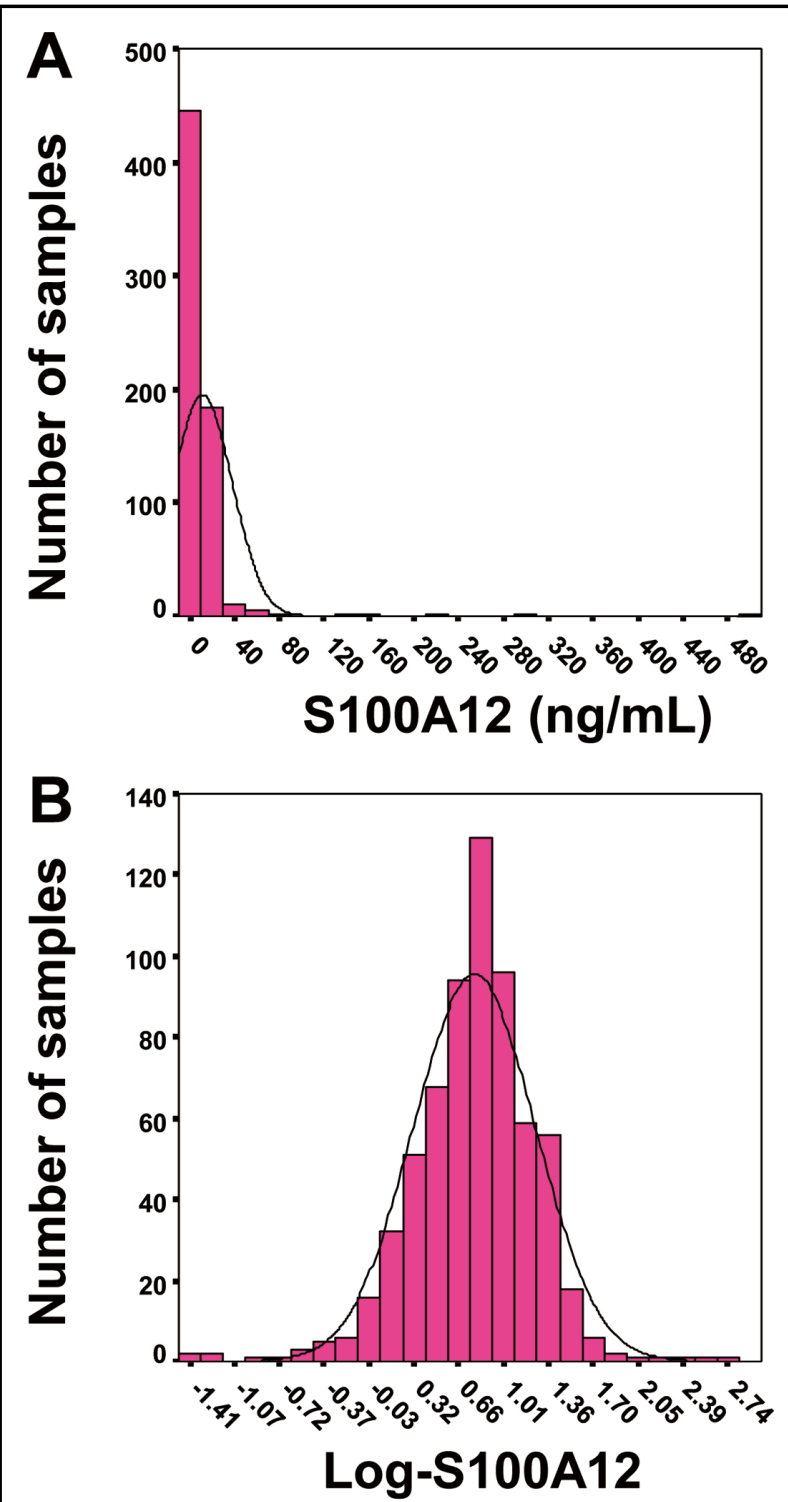

Figure 1. (A) Plasma S100A12 level was not normally distributed, therefore it was (B) logarithmically transformed. (A) Mean plasma S100A12 was $11.1 \pm 26.6 \mathrm{ng} / \mathrm{ml}(\mathrm{SE}, 1.04 \mathrm{ng} / \mathrm{ml})$. The $95 \%$ confidence interval ranged from 9.05 to $13.14 \mathrm{ng} / \mathrm{ml}$. Maximum and minimum values were 0.039 and $498.4 \mathrm{ng} / \mathrm{ml}$, respectively. Median S100A12 level was $6.50 \mathrm{ng} / \mathrm{ml}$. LogS100A12, logarithmically transformed plasma S100A12.

The plasma concentration of S100A12 was determined using enzyme-linked immunosorbent assay (ELISA) kits according to the manufacturer's instructions (Cyclex, Nagano, Japan). The lower limit of S100A12 detection was $78 \mathrm{pg} / \mathrm{ml}$. The intraand inter-assay variation of the kit was $3.0 \%$ and $6.6 \%$, respectively. The kit does not detect other $\mathrm{S} 100$ proteins such as S100A8 and 9. The sampling time and feeding did not influence the measurement of S100A12.

High-sensitivity C-reactive protein (hs-CRP) was measured using the latex nephelometry method described by Ledue et al. ${ }^{21}$

\section{Statistical Analysis}

All data are expressed as mean \pm SEM unless otherwise indicated. The significance of differences between 4 groups was 
determined using Jonckheere-Terpstra test. Categorical variables were expressed as percentages and analyzed using chisquare test. Correlations were analyzed using Spearman's correlation coefficient. Multiple regression, Kaplan-Meier survival curve and Cox proportional hazard model analyses were conducted using SPSS version 16.0 (SPSS, Chicago, IL, USA). $\mathrm{P}<0.05$ was considered significant.

\section{Results}

\section{Baseline Subject Characteristics}

A total of 652 patients (age 29-85 years) were studied. The baseline subject characteristics are listed in Table 1 . In the case of cardiac catheterization, 997 lesions were treated (1.53 lesions/patient). Two hundred and eighty-six (28.8\%) were in the right coronary artery, $436(43.7 \%)$ in the left anterior descending artery, $228(22.9 \%)$ in the left circumflex artery, 33 $(3.3 \%)$ in the left main trunk and $14(1.4 \%)$ in the vein graft lesions. Nine hundred and forty-five lesions were treated with coronary stents, including 712 drug-eluting stents and 233 bare metal stents. One lesion was treated with a cutting balloon, 30 lesions by plain old balloon angioplasty, 4 lesions by directional coronary atherectomy and 17 lesions with rotational atherectomy.

\section{Plasma S100A12 Level and Clinical Parameters}

The distribution of plasma S100A12 is given in Figure 1. Mean plasma S100A12 was $11.1 \mathrm{ng} / \mathrm{ml}$ with SD of $26.6 \mathrm{ng} / \mathrm{ml}$ and SE, $1.04 \mathrm{ng} / \mathrm{ml}$. The $95 \%$ confidence interval ranged from 9.05 to $13.14 \mathrm{ng} / \mathrm{ml}$. Maximum and minimum values were 0.039 and $498.4 \mathrm{ng} / \mathrm{ml}$, respectively. The median S100A12 was $6.50 \mathrm{ng} / \mathrm{ml}$. As shown in Figure 1A, S100A12 level did not have a normal distribution, therefore it was logarithmically transformed (Figure 1B).

First, we examined the simple correlation between plasma S100A12 level and clinical parameters. Similar to S100A12,

\begin{tabular}{|lcr|}
\hline \multicolumn{3}{|c|}{ Table 2. Plasma S100A12 and Clinical Parameters } \\
Clinical parameters & $\begin{array}{c}\text { Correlation } \\
\text { coefficient }\end{array}$ & P value \\
Age $($ years $)$ & +0.071 & 0.072 \\
BMl $\left(\mathrm{kg} / \mathrm{m}^{2}\right)$ & -0.022 & 0.570 \\
WBC count $(\mu \mathrm{l})$ & +0.148 & $<0.001$ \\
RBC count $\left(\times 10^{4} / \mu \mathrm{l}\right)$ & -0.095 & 0.015 \\
Platelet count $\left(\times 10^{4} / \mu \mathrm{l}\right)$ & +0.084 & 0.033 \\
HbA $1 \mathrm{c}(\%)$ & +0.058 & 0.145 \\
AST $(\mathrm{IU} / \mathrm{L})$ & +0.066 & 0.092 \\
ALT $(\mathrm{IU} / \mathrm{L})$ & -0.013 & 0.745 \\
TC $(\mathrm{mg} / \mathrm{dl})$ & +0.020 & 0.618 \\
Triglyceride $(\mathrm{mg} / \mathrm{dl})$ & +0.011 & 0.786 \\
LDL-C $(\mathrm{mg} / \mathrm{dl})$ & +0.027 & 0.506 \\
HDL-C $(\mathrm{mg} / \mathrm{dl})$ & +0.024 & 0.546 \\
hs-CRP $(\mathrm{ng} / \mathrm{ml}, \mathrm{log})$ & +0.248 & 0.001 \\
eGFR $\left(\mathrm{ml} \cdot \mathrm{min}^{-1} \cdot 1.73 \mathrm{~m}^{-2}\right)$ & -0.027 & 0.488 \\
LVEF $(\%)$ & -0.069 & 0.080 \\
\hline
\end{tabular}

Triglyceride, hs-CRP and S100A12 data were logarithmically transformed due to non-parametric distribution.

ALT, alanine aminotransferase; AST, aspartate aminotransferase; $\mathrm{HbA}_{1 c}$, hemoglobin $\mathrm{A}_{1 c}$; HDL-C, high-density lipoprotein cholesterol; LDL-C, low-density lipoprotein cholesterol; RBC, red blood cell; TC, total cholesterol; WBC, white blood cell. Other abbreviations as in Table 1.

we used logarithmically transformed triglyceride and hs-CRP in the data analysis, because they did not follow a Gaussian distribution. Table 2 lists the correlation between plasma S100A12 level and clinical parameters. The white blood cell count, the platelet count and hs-CRP had a significant positive correlation with plasma S100A12. The red blood cell count and plasma S100A12 level had a significant negative correlation. We then conducted multivariate linear regression analysis

\begin{tabular}{|c|c|c|c|c|}
\hline S100A12 quartile & Q1 & Q2 & Q3 & Q4 \\
\hline Age (years), mean $\pm S D$ & $63.3 \pm 9.8$ & $63.6 \pm 9.4$ & $65.5 \pm 8.9$ & $63.9 \pm 10.1$ \\
\hline Gender (M/F) & $129 / 34$ & $141 / 22$ & $125 / 38$ & $138 / 25$ \\
\hline BMI $\left(\mathrm{kg} / \mathrm{m}^{2}\right)$ & $24.3 \pm 0.3$ & $24.3 \pm 0.2$ & $23.8 \pm 0.2$ & $24.3 \pm 0.3$ \\
\hline Hypertension & $115(71)$ & $126(77)$ & $126(83)$ & $120(74)$ \\
\hline Dyslipidemia & $112(69)$ & $105(64)$ & $98(60)$ & $112(69)$ \\
\hline DM & $59(36)$ & $70(43)$ & $71(44)$ & $78(48)$ \\
\hline Smoking & $108(66)$ & $122(75)$ & $108(66)$ & $125(77)$ \\
\hline $\mathrm{FH}$ of $\mathrm{CAD}$ & $32(20)$ & $39(24)$ & $31(19)$ & $37(23)$ \\
\hline WBC $(\mu \mathrm{l})$ & $6,223 \pm 1,202$ & $6,644 \pm 1,375$ & $6,465 \pm 122$ & $7,022 \pm 142^{\dagger}$ \\
\hline $\mathrm{RBC}\left(\times 10^{4} / \mu \mathrm{l}\right)$ & $435 \pm 5$ & $431 \pm 5$ & $423 \pm 5$ & $429 \pm 47$ \\
\hline Platelet $(\times 104 / \mu \mathrm{l})$ & $21.4 \pm 0.5$ & $23.7 \pm 0.5$ & $22.2 \pm 0.5$ & $24.5 \pm 0.8^{\S}$ \\
\hline $\mathrm{HbA}_{1 \mathrm{c}}(\%)$ & $5.97 \pm 0.10$ & $6.21 \pm 0.11$ & $6.05 \pm 0.08$ & $6.22 \pm 0.10$ \\
\hline TC (mg/dl) & $189 \pm 2.8$ & $189 \pm 3.0$ & $189 \pm 3.0$ & $193 \pm 3.4$ \\
\hline Triglyceride (mg/dl) & $148 \pm 7.0$ & $154 \pm 6.8$ & $146 \pm 6.1$ & $169 \pm 8.4$ \\
\hline LDL-C (mg/dl) & $110 \pm 2.6$ & $109 \pm 2.7$ & $112 \pm 2.6$ & $110 \pm 1.3$ \\
\hline HDL-C (mg/dl) & $48 \pm 1.1$ & $47 \pm 1.0$ & $48 \pm 1.1$ & $48 \pm 1.1$ \\
\hline hs-CRP (ng/ml) & $1,314 \pm 248$ & $2,036 \pm 475$ & $3,422 \pm 720$ & $4,735 \pm 618^{\dagger}$ \\
\hline eGFR $\left(\mathrm{ml} \cdot \mathrm{min}^{-1} \cdot 1.73 \mathrm{~m}^{-2}\right)$ & $67.5 \pm 1.6$ & $69.3 \pm 1.5$ & $69.4 \pm 1.8$ & $66.2 \pm 2.0$ \\
\hline LVEF (\%) & $62.0 \pm 0.98$ & $61.7 \pm 0.95$ & $60.0 \pm 1.05$ & $59.1 \pm 1.14^{*}$ \\
\hline $\mathrm{S} 100 \mathrm{~A} 12(\mathrm{ng} / \mathrm{ml})$ & $1.89 \pm 0.07$ & $4.98 \pm 0.07$ & $8.64 \pm 0.12$ & $28.9 \pm 3.84^{\dagger}$ \\
\hline
\end{tabular}

Data given as mean \pm SEM or $n(\%)$. ${ }^{*} \mathrm{P}<0.05 ; \mathrm{S} P<0.01 ;{ }^{\dagger} \mathrm{P}<0.001$.

Abbreviations as in Tables 1,2. 


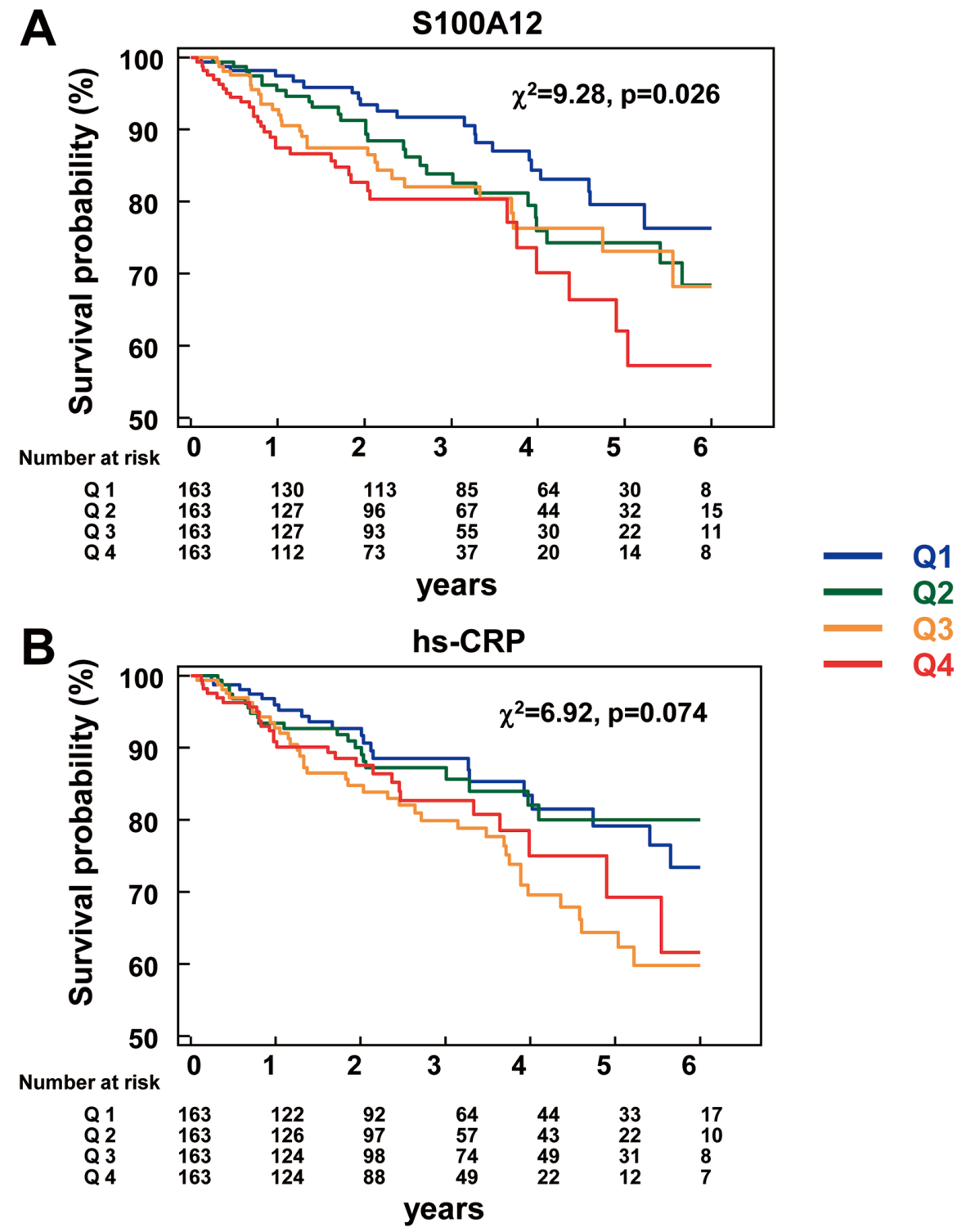

Figure 2. Kaplan-Meier curve analysis. (A) Survival probability from major adverse cardiovascular events (MACE) in coronary artery disease patients according to quartile of plasma S100A12 level after successful percutaneous coronary intervention. Q4 had a significantly higher MACE rate than $\mathrm{Q} 1$ (log-rank test, $X^{2}=9.28, P=0.026$ ). Post-hoc analysis showed that the difference in MACE rates between $Q 1$ and $Q 4$ was significant $(P=0.002)$. (B) Survival probability for MACE in high-sensitivity C-reactive protein (hs-CRP) quartiles (log-rank test, $\left.X^{2}=6.92, P=0.074\right)$.

using a stepwise method (forward entry model). We set plasma S100A12 level as a responsive variable and the white blood cell count, red blood cell count, platelet count and hs-CRP as explanatory variables. We found that hs-CRP was significantly associated with plasma S100A12 level $(\beta=+0.246, \mathrm{P}<0.001)$.

\section{S100A12 Level as a Predictor of MACE in Chronic CAD Patients}

Next, we examined whether plasma S100A12 can be used to predict MACE after successful PCI. The mean follow-up period was $973 \pm 639$ days (25-2,190 days). MACE occurred in 108 patients $(16.6 \%)$. Recurrence of angina pectoris occurred in 48 patients. Of these, 26 patients had restenosis of target vessels and 22 patients had new stenotic lesions. Two patients were treated medically, 9 patients by balloon angioplasty, 36 by coronary stent implantation and 1 patient by coronary bypass surgery. Arrhythmic events occurred in 2 patients. One patient had atrial fibrillation with complete atrioventricular block and was treated with permanent pacemaker implantation. One patient was re-admitted due to ventricular tachycardia and was treated with oral amiodarone.

We divided the patients into 4 groups based on the percentile of plasma S100A12 level ( $n=163$, respectively). The quartiles were: $0.039-<3.384 \mathrm{ng} / \mathrm{ml}$ (Q1, first quartile), 3.384$<6.503 \mathrm{ng} / \mathrm{ml}$ (Q2, second quartile), 6.503-<11.414 ng/ml (Q3, third quartile), and $11.414-498.4 \mathrm{ng} / \mathrm{ml}$ (Q4, fourth quartile). The mean S100A12 in Q1, Q2, Q3 and Q4 was $1.89 \pm 0.07 \mathrm{ng} / \mathrm{ml}$, $4.98 \pm 0.07 \mathrm{ng} / \mathrm{ml}, 8.64 \pm 0.12 \mathrm{ng} / \mathrm{ml}$, and $28.9 \pm 3.84 \mathrm{ng} / \mathrm{ml}$, re- 


\begin{tabular}{lrrrr}
\hline Table 4. Cardiovascular Events vs. S100A12 Quartile \\
\multicolumn{1}{c}{ S100A12 quartile } & Q1 & Q2 & Q3 & Q4 \\
Congestive heart failure & 4 & 7 & 6 & 12 \\
Readmission due to angina pectoris & 11 & 13 & 14 & 10 \\
Acute myocardial infarction & 1 & 5 & 1 & 5 \\
Stroke & 0 & 0 & 3 & 2 \\
Critical arrhythmia & 1 & 0 & 1 & 0 \\
Intervention to peripheral arteries & 4 & 0 & 1 & 2 \\
Cardiac death & 0 & 2 & 2 & 1 \\
MACE & 21 & 27 & 28 & 32 \\
\hline
\end{tabular}

MACE, major adverse cardiovascular event (defined as composite events of readmission for congestive heart failure, readmission due to recurrence of angina pectoris, acute myocardial infarction, stroke, critical arrhythmia, intervention to peripheral arteries and cardiac death).

spectively. Table 3 lists the subject baseline clinical characteristics according to quartile. White blood cell count, platelet count, hs-CRP and LVEF were significantly different among the 4 groups. As shown in Figure 2A, MACE rate was statistically significant among 4 groups according to Kaplan-Meier curve (log-rank test, $\chi^{2}=9.28, \mathrm{P}=0.026$ ). On post-hoc analysis the difference in the MACE rate between Q1 and Q4 was significant $(\mathrm{P}=0.002)$. Because there was a significant correlation between S100A12 and hs-CRP, we also examined whether hs-CRP could predict MACE. We divided patients into 4 groups according to the percentile of hs-CRP (median, $762 \mathrm{ng} / \mathrm{ml}$; Q1, 50-<304.5 ng/ml; Q2, 304.5-<762 ng/ml; Q3, $762-<1,900 \mathrm{ng} / \mathrm{ml}$; Q4, 1,900-88,200 ng/ml). As shown in Figure 2B, on Kaplan-Meier curve analysis the difference of the MACE rate in hs-CRP quartiles was not significant (log rank test, $\left.\chi^{2}=6.92, \mathrm{P}=0.074\right)$. We summarized the cardiovascular events in 4 groups (Table 4).

We analyzed the independent factors associated with MACE. We performed multivariate Cox proportional hazard model analysis with the stepwise method (forward entry). In model 1, we used demographic data (age, sex), classical coronary risk factors (hypertension, dyslipidemia, diabetes mellitus, smoking, family history of CAD, and body mass index) and S100A12 level as explanatory variables. We found that hypertension, diabetes mellitus and S100A12 were independent factors for predicting MACE (Table 5). In model 2, we added established factors for predicting MACE (estimated glomerular filtration rate [eGFR], hs-CRP, LVEF, history of myocardial infarction, number of major stenotic vessels, and intervention without drug-eluting stents; using plain balloon angioplasty alone, atherectomy alone and bare metal stents) to model 1 as explanatory variables. As shown in Table 3, hypertension, eGFR, LVEF and S100A12 level were significant factors for predicting MACE. In model 3, we used systolic blood pressure, triglyceride, low-density lipoprotein, high-density lipoprotein, hemoglobin $\mathrm{A}_{1 \mathrm{c}}\left(\mathrm{HbA}_{1 \mathrm{c}}\right)$, and Brinkman index instead of hypertension, dyslipidemia, diabetes mellitus, and smoking as explanatory variables in model 2 , respectively. In this model, we found that systolic blood pressure, HbA1c, eGFR, LVEF and S100A12 level were significant factors for predicting MACE.

We further analyzed the significance of S100A12 for each cardiovascular event in the S100A12 quartiles. Kaplan-Meier curve analysis showed that plasma S100A12 level was significantly associated with $\mathrm{CHF}(\mathrm{P}=0.043)$ and stroke $(\mathrm{P}=0.044)$. Cox analysis (model 3 ) showed that $\mathrm{S} 100 \mathrm{~A} 12$ was a significant independent predictor for $\mathrm{CHF}$ (hazard ratio, 2.44; 95\% confidence interval: 1.03-5.79, $\mathrm{P}=0.043$ ) together with $\mathrm{HbA}$ c, eGFR,

\begin{tabular}{|c|c|c|}
\hline \multicolumn{3}{|c|}{$\begin{array}{l}\text { Table 5. Independent Factors for Predicting MACE in CAD } \\
\text { Patients }\end{array}$} \\
\hline & HR (95\% Cl) & $P$ value \\
\hline \multicolumn{3}{|l|}{ Model 1} \\
\hline Hypertension & $2.66(1.49-4.75)$ & 0.001 \\
\hline Diabetes mellitus & $1.52(1.04-2.22)$ & 0.031 \\
\hline $\mathrm{S} 100 \mathrm{~A} 12(\mathrm{ng} / \mathrm{ml})$ & $1.80(1.17-2.76)$ & 0.007 \\
\hline \multicolumn{3}{|l|}{ Model 2} \\
\hline Hypertension & $2.56(1.43-4.59)$ & 0.002 \\
\hline eGFR $\left(\mathrm{ml} \cdot \mathrm{min}^{-1} \cdot 1.73 \mathrm{~m}^{-2}\right)$ & $0.99(0.98-1.00)$ & 0.004 \\
\hline LVEF (\%) & $0.97(0.96-0.98)$ & $<0.001$ \\
\hline S100A12 (ng/ml) & $1.59(1.05-2.42)$ & 0.030 \\
\hline \multicolumn{3}{|l|}{ Model 3} \\
\hline Systolic blood pressure & $1.01(1.00-1.02)$ & 0.004 \\
\hline $\mathrm{HbA}_{1 \mathrm{c}}(\%)$ & $1.19(1.05-1.35)$ & 0.009 \\
\hline eGFR $\left(\mathrm{ml} \cdot \mathrm{min}^{-1} \cdot 1.73 \mathrm{~m}^{-2}\right)$ & $0.99(0.98-1.00)$ & 0.005 \\
\hline $\operatorname{LVEF}(\%)$ & $0.97(0.96-0.99)$ & $<0.001$ \\
\hline $\mathrm{S} 100 \mathrm{~A} 12(\mathrm{ng} / \mathrm{ml})$ & $1.64(1.06-2.53)$ & 0.025 \\
\hline
\end{tabular}

S100A12 data were logarithmically transformed due to non-parametric distribution.

$\mathrm{Cl}$, confidence interval; HR, hazard ratio. Other abbreviations as in Tables 1,4.

and LVEF. The incidence of stroke was too small to perform Cox analysis. We found a weak association between plasma S100A12 level and acute myocardial infarction, although on log-rank test it was not statistically significant $(\mathrm{P}=0.059)$.

\section{Discussion}

The present study has shown that plasma S100A12 level is associated with hs-CRP level, suggesting that S100A12 reflects inflammation in patients with stable CAD. Inflammation might account for the relationship between S100A12 and blood cell count. Interestingly, plasma S100A12 level was consistently associated with cardiovascular events in our models. In contrast, we did not find a significant association between hs-CRP and MACE in the present subjects.

S100A12 is abundantly expressed in white blood cells. $9,22,23$ Foell et al reported that infliximab, an anti-tumor necrosis factor- $\alpha$ antibody, rapidly reduced S100A12 level, suggesting positive feedback mechanisms for S100A12 and other inflammatory cytokines. ${ }^{11}$ In addition, the ligation of S100A12 to RAGE activates $\mathrm{NF} \kappa \mathrm{B}$, leading to numerous inflammatory steps. Interestingly, expression of soluble RAGE has been reported to be elevated in patients with acute myocardial infarction. ${ }^{24}$ The S100A8/9 heterodimer, another S100A protein, has been associated with an increased risk of cardiovascular events in a case-control study using patients enrolled in the PROVEITTIMI22 trial. $^{25}$

In the present study, S100A12 was a significant predictor of MACE in patients with stable CAD. In particular, S100A12 was a predictor for the occurrence of CHF. We still do not know the precise role of S100A12 in CHF. We speculate that S100A12 is associated with impairment of the cardiac microcirculation and endothelial dysfunction in patients with CAD. Although S100A12 seemed to be related to the stroke, the number of events was too small to obtain confident results.

In contrast to S100A12, hs-CRP was not significant for predicting MACE in the present subjects. S100A12 showed a concentration-dependent increase in the MACE rate, whereas hs-CRP did not show such a relationship. It is possible that 
inflammation not related to cardiovascular systems might have contributed to the elevation of hs-CRP. Previous studies have demonstrated that hs-CRP is a useful biomarker to predict MACE in various cardiovascular diseases. ${ }^{26,27}$ A larger number of subjects might show hs-CRP as a prognostic marker using the present study design. S100A12 might be a specific marker of the pathological process in the cardiovascular system. Similar to S100A, previous reports have shown the clinical significance of pentraxin 3 in cardiovascular disease. ${ }^{28-30}$ Furthermore, procalcitonin, a bacterial infection marker, has been reported to be a marker to predict cardiovascular events. ${ }^{31}$ These novel and specific biomarkers are needed for the risk stratification of patients with cardiovascular disease.

In conclusion, plasma S100A12 level could be a novel biomarker for predicting MACE in patients with stable CAD. Further study using a larger number of subjects is needed to clarify the precise role of S100A12 in cardiovascular disease.

\section{Study Limitations}

First, we measured the level of S100A12 before PCI. It might be useful to follow the changes in plasma S100A12 level after PCI to provide more information about the relationship between S100A12 and MACE in chronic CAD patients.

Second, plasma S100A12 level was below the detection limit in 4 patients. We calculated S100A12 concentration using the standard regression curve of ELISA in these subjects. Their measurements were $39 \mathrm{pg} / \mathrm{ml}, 39 \mathrm{pg} / \mathrm{ml}, 47 \mathrm{pg} / \mathrm{ml}$ and $68 \mathrm{pg} / \mathrm{ml}$, respectively. These data might be inaccurate because they are under the detection limit.

Finally, the number of events such as acute myocardial infarction, re-vascularization of peripheral arteries and cardiac death was small. Further study is needed with a larger number of subjects to confirm the significance of S100A12 in these events.

\section{Acknowledgment}

We thank Takako Takagi for her excellent technical assistance.

\section{References}

1. Moses JW, Leon MB, Popma JJ, Fitzgerald PJ, Holmes DR, O'Shaughnessy C, et al. Sirolimus-eluting stents versus standard stents in patients with stenosis in a native coronary artery. $N$ Engl $J$ Med 2003; 349: 1315-1323.

2. Holmes DRJ, Leon MB, Moses JW, Popma JJ, Cutlip D, Fitzgerald $\mathrm{PJ}$, et al. Analysis of 1-year clinical outcomes in the SIRIUS trial: A randomized trial of a sirolimus-eluting stent versus a standard stent in patients at high risk for coronary restenosis. Circulation 2004; 109: $634-640$.

3. Weisz G, Leon MB, Holmes DRJ, Kereiakes DJ, Clark MR, Cohen $\mathrm{BM}$, et al. Two-year outcomes after sirolimus-eluting stent implantation: Results from the Sirolimus-Eluting Stent in de Novo Native Coronary Lesions (SIRIUS) trial. J Am Coll Cardiol 2006; 47: 1350-1355.

4. Weisz G, Leon M, Holmes DRJ, Kereiakes D, Popma J, Teirstein P, et al. Five-year follow-up after sirolimus-eluting stent implantation: Results of the SIRIUS (Sirolimus-Eluting Stent in De-Novo Native Coronary Lesions) trial. J Am Coll Cardiol 2009; 53: 1488-1497.

5. Kastrati A, Mehilli J, Pache J, Kaiser C, Valgimigli M, Kelbaek H, et al. Analysis of 14 trials comparing sirolimus-eluting stents with bare-metal stents. N Engl J Med 2007; 356: 1030-1039.

6. Hofmann MA, Drury S, Fu C, Qu W, Taguchi A, Lu Y, et al. RAGE mediates a novel proinflammatory axis: A central cell surface receptor for S100/calgranulin polypeptides. Cell 1999; 97: 889-901.

7. Rosario D. S100: A multigenic family of calcium-modulated proteins of the EF-hand type with intracellular and extracellular functional roles. Int J Biochem Cell Biol 2001; 33: 637-668.

8. Marenholz I, Heizmann CW, Fritz G. S100 proteins in mouse and man: From evolution to function and pathology (including an update of the nomenclature). Biochem Biophys Res Commun 2004; 322: $1111-1122$.

9. Vogl T, Pröpper C, Hartmann M, Strey A, Strupat K, van den Bos C, et al. S100A12 is expressed exclusively by granulocytes and acts independently from MRP8 and MRP14. J Biol Chem 1999; 274: 25291-25296.

10. Yang Z, Tao T, Raftery MJ, Youssef P, Di Girolamo N, Geczy CL. Proinflammatory properties of the human S100 protein S100A12. $J$ Leukoc Biol 2001; 69: 986-994.

11. Foell D, Kucharzik T, Kraft M, Vogl T, Sorg C, Domschke W, et al. Neutrophil derived human S100A12 (EN-RAGE) is strongly expressed during chronic active inflammatory bowel disease. Gut 2003; 52: $847-853$.

12. Foell D, Seeliger S, Vogl T, Koch HG, Maschek H, Harms E, et al. Expression of S100A12 (EN-RAGE) in cystic fibrosis. Thorax 2003; 58: $613-617$.

13. Niini T, Vettenranta K, Hollmén J, Larramendy ML, Aalto Y, Wikman $\mathrm{H}$, et al. Expression of myeloid-specific genes in childhood acute lymphoblastic leukemia: A cDNA array study. Leukemia 2002; 16: 2213-2221.

14. Ye F, Foell D, Hirono KI, Vogl T, Rui C, Yu X, et al. Neutrophilderived S100A12 is profoundly upregulated in the early stage of acute Kawasaki disease. Am J Cardiol 2004; 94: 840-844.

15. Hofmann MA, Drury S, Hudson BI, Gleason MR, Qu W, Lu Y, et al. RAGE and arthritis: The G82S polymorphism amplifies the inflammatory response. Genes Immun 2002; 3: 123-135.

16. Foell D, Kane D, Bresnihan B, Vogl T, Nacken W, Sorg C, et al. Expression of the pro-inflammatory protein S100A12 (EN-RAGE) in rheumatoid and psoriatic arthritis. Rheumatology (Oxford) 2003; 42: $1383-1389$.

17. Foell D, Ichida F, Vogl T, Yu X, Chen R, Miyawaki T, et al. S100A12 (EN-RAGE) in monitoring Kawasaki disease. Lancet 2003; 361: $1270-1272$.

18. Japanese Society of Hypertension Guidelines Subcommittee for the Management of Hypertension. Guidelines for the management of hypertension for general practitioners. Hypertens Res 2001; 24: 613-634.

19. Teramoto T. Japan Atherosclerosis Society guidelines for prevention of atherosclerotic diseases in Japanese. Nihon Ronen Igakkai Zasshi 2008; 45: 597-600.

20. Kosaka K. Diagnosis of diabetes mellitus. Nihon Naika Gakkai Zasshi 1982; 71: 759-763.

21. Ledue TB, Weiner DL, Sipe JD, Poulin SE, Collins MF, Rifai N. Analytical evaluation of particle-enhanced immunonephelometric assays for C-reactive protein, serum amyloid A and mannose-binding protein in human serum. Ann Clin Biochem 1998; 35: 745-753.

22. Moroz OV, Dodson GG, Wilson KS, Lukanidin E, Bronstein IB. Multiple structural states of S100A12: A key to its functional diversity. Microsc Res Tech 2003; 60: 581-592.

23. Foell D, Wittkowski H, Vogl T, Roth J. S100 proteins expressed in phagocytes: A novel group of damage-associated molecular pattern molecules. J Leukoc Biol 2007; 81: 28-37.

24. Park H, Baek J, Shin W, Kim D, Jang S, Shin D, et al. Soluble receptor of advanced glycated endproducts is associated with plaque vulnerability in patients with acute myocardial infarction. Circ J 2011; 75: $685-690$.

25. Morrow DA, Wang Y, Croce K, Sakuma M, Sabatine MS, Gao H, et al. Myeloid-related protein $8 / 14$ and the risk of cardiovascular death or myocardial infarction after an acute coronary syndrome in the Pravastatin or Atorvastatin Evaluation and Infection Therapy: Thrombolysis in Myocardial Infarction (PROVE IT-TIMI 22) trial. Am Heart J 2008; 155: 49-55.

26. Lagrand WK, Visser CA, Hermens WT, Niessen HW, Verheugt FW, Wolbink GJ, et al. C-reactive protein as a cardiovascular risk factor: More than an epiphenomenon? Circulation 1999; 100: 96-102.

27. Zebrack JS, Muhlestein JB, Horne BD, Anderson JL; Intermountain Heart Collaboration Study Group. C-reactive protein and angiographic coronary artery disease: Independent and additive predictors of risk in subjects with angina. $J$ Am Coll Cardiol 2002; 39: 632-637.

28. Ishino M, Takeishi Y, Niizeki T, Watanabe T, Nitobe J, Miyamoto $\mathrm{T}$, et al. Risk stratification of chronic heart failure patients by multiple biomarkers: Implications of BNP, H-FABP, and PTX3. Circ J 2008; 72: 1800-1805.

29. Ferratini M, Ripamonti V, Masson S, Grati P, Racca V, Cuccovillo $\mathrm{I}$, et al. Pentraxin-3 predicts functional recovery and 1-year major adverse cardiovascular events after rehabilitation of cardiac surgery patients. J Cardiopulm Rehabil Prev 2012; 32: 17-24.

30. Matsubara J, Sugiyama S, Nozaki T, Sugamura K, Konishi M, Ohba $\mathrm{K}$, et al. Pentraxin 3 is a new inflammatory marker correlated with left ventricular diastolic dysfunction and heart failure with normal ejection fraction. J Am Coll Cardiol 2011; 57: 861-869.

31. Sinning C, Sinning J, Schulz A, Schnabel R, Lubos E, Wild P, et al. Association of serum procalcitonin with cardiovascular prognosis in coronary artery disease. Circ J 2011; 75: 1184-1191. 